\title{
Effect of Substrate Depth on Initial Growth, Coverage, and Survival of 25 Succulent Green Roof Plant Taxa
}

\author{
Angela K. Durhman and D. Bradley Rowe ${ }^{1}$ \\ Department of Horticulture, Michigan State University, A212 Plant \& Soil \\ Sciences Building, East Lansing, MI 48824
}

Clayton L. Rugh

Department of Crop and Soil Sciences, Michigan State University, East Lansing, MI 48824

Additional index words. vegetative roof, eco-roof, living roof, plant evaluations, Graptopetalum, Phedimus, Rhodiola, Sedum, Crassulaceae

\begin{abstract}
Because of greater interest in green roofs in the United States, it is critical to increase the number and geographic range of proven plant resources for long-term survival on rooftops. Successful plant taxa for extensive green roofs must establish themselves quickly, provide high groundcover density, and tolerate extreme environmental conditions. Furthermore, dead load weight restrictions on many buildings may limit the substrate depth that can be applied. The objective of this study was to evaluate the effect of substrate depth on initial establishment and survival of 25 succulent plant taxa for green roof applications in the midwestern United States. Survival, initial growth, and rate of coverage were compared for plants grown in three substrate depths $(2.5,5.0$, and $7.5 \mathrm{~cm}$ ) on 24 roof platforms. Plant coverage was determined from image analysis of weekly digital photographs. Results indicate deeper substrates promote greater survival and growth; however, in the shallowest depth of $2.5 \mathrm{~cm}$, several species continued to persist. Of the 25 species initially planted, only $47 \%$ survived in the deepest substrate of $7.5 \mathrm{~cm}$. Recommended species at the depths tested for climates similar to southern Michigan include Phedimus spurious Raf. 'Leningrad White', Sedum acre L., S. album L. 'Bella d'Inverno', S. middendorffianum L., S. reflexum L., S. sediforme J., and $S$. spurium Bieb. 'Summer Glory'. Subsidiary species that are present at specific substrate depths but may not exhibit an ability to cover large areas include $S$. dasyphyllum $\mathbf{L}$. 'Burnatii', $S$. dasyphyllum L. 'Lilac Mound', S. diffusum W., S. hispanicum L., and S. kamtschaticum Fisch. The primary deterrent for these subsidiary species was little to no survival at 2.5 $\mathrm{cm}$. Deeper substrates promoted greater survival and growth for nearly all species tested.
\end{abstract}

Vegetated green roofs provide numerous benefits to the built environment such as a reduction in stormwater runoff, building insulation, and mitigation of the urban heat island effect (DeNardo et al., 2005; Getter and Rowe, 2006; Liu, 2004; VanWoert et al., 2005a). Many extensive (shallow) green roofs consist primarily of low-maintenance succulent perennial species such as Sedum L., Delosperma N.E.Br., and Sempervivum L.; grasses like Festuca L.; and herbaceous plants such as Allium L. and Dianthus L. (Dunnett and Kingsbury, 2004; Dunnett and

\footnotetext{
Received for publication 10 Dec. 2006. Accepted for publication $23 \mathrm{Feb} .2007$.

Funding for this study was provided by Ford Motor Company, Dearborn, Mich.; ChristenDETROIT Roofing Contractors, Detroit, Mich.; Wolfgang Behrens Systementwicklung, GmbH, Groß Ippener, Germany; International Sedum Society, Northumberland, U.K.; Perennial Plant Association; Michigan Department of Agriculture; and the Michigan Agricultural Experiment Station.

This paper is a portion of an MS thesis submitted by Angela K. Durhman.

${ }^{1}$ To whom reprint requests should be addressed; e-mail rowed@msu.edu
}

Nolan, 2004; Köehler, 2003; Snodgrass and Snodgrass, 2006). As more green roofs become established in the United States, it is critical to increase the number and geographic range of proven plant resources for long-term survival on rooftops.

Likely candidates can be found in extreme environments such as rock outcroppings or under alpine conditions. Species classified as chamaephytes grow in alpine regions where snow cover protects the shoots and buds against water loss. Chamaephytes are subshrubs and herbs with vegetative shoots that lie along the ground and remain intact at the beginning of an unfavorable season (Raunkiaer, 1934). Sedum are classified as passive chamaephytes because response during unfavorable conditions results in shorter internodal length and reduced shoot lengths. In terms of growth habit, their low-growing, spreading groundcover characteristics make them ideal for covering extensive green roofs. Plants that cover the substrate in a short period of time reduce potential erosion problems and inhibit weeds. Species that are long-lived, reseed themselves, or spread vegetatively should continue to provide $100 \%$ coverage as long as environmental conditions are favorable. German guidelines require at least $60 \%$ vegetative coverage to be approved as a green roof (FLL, 1995).

In addition to morphologic and growth habit characteristics, many succulents are ideal for extensive green roofs because they are physiologically adapted to withstand harsh environmental conditions (Gebauer, 1988). Some have been documented to exhibit Crassulacean acid metabolism (CAM), a metabolic pathway that enables them to adapt to water-stressed environmental conditions (Gebauer, 1988; Sayed, 2001; Ting, 1985). CAM plants usually have fewer stomata than $\mathrm{C}_{3}$ and $\mathrm{C}_{4}$ plants, and these stomata can open at night for the uptake of $\mathrm{CO}_{2}$, thus reducing daytime water loss. In a controlled greenhouse study, Durhman et al. (2006) found that several species of Sedum survived and maintained active photosynthetic metabolism even after 4 months without water. Another drought-resistant mechanism of CAM plants is to store water in the succulent leaves (Sayed, 2001).

In northern climates, winter cold hardiness is a major factor in overwintering survival. In Madrid, Spain, researchers found that when subjected to $10{ }^{\circ} \mathrm{C}$ for $11 \mathrm{~h}$, $S$. forsterianum $\mathrm{Sm}$. and various strains of $S$. album L. suffered, but $S$. micranthum Bast., S. rupestre L., and $S$. ochroleucum Chaix all survived at a substrate depth of $3.5 \mathrm{~cm}$ (Gómez-Campo, 1996). In North America, Boivin et al. (2001) reported that, for the six species tested in Quebec, greater freezing injury occurred at shallow substrate depths of $5 \mathrm{~cm}$ compared with $9 \mathrm{~cm}$ or 11.5 $\mathrm{cm}$. Monterusso et al. (2005) compared 18 native forbs and grasses with nine species of Sedum over three seasons (2001-2004) on a roof platform in Michigan. All nine of the Sedum thrived, but only four of the 18 native taxa were found to be acceptable in $10 \mathrm{~cm}$ of substrate. It is important to note that although Quebec experiences colder winters than Michigan, the Quebec study was conducted on a heated building, whereas the Monterusso study and this study took place on unheated roof platforms.

The U.S. Dept. of Agriculture (USDA) has developed a plant hardiness zone map to quantify average annual minimum temperature data for the purpose of predicting plant survival. Many ornamental plant species have been assigned to a range of hardiness zones where they are most likely to survive. However, some of the species and cultivars examined in this study have not been previously reported for use on Michigan green roofs and do not have published USDA hardiness zones. Thus, this study offers new plant recommendations for locations with similar climates.

Successful candidates for extensive green roofs exhibit characteristics such as rapid establishment, high groundcover density, tolerance to extreme environmental conditions, and successful winter recovery (ASTM, 2006; Getter and Rowe, 2006). Substrate depth can influence all of these factors. Longterm persistence is also important because 
green roofs are dynamic systems. However, this article concentrates on initial establishment. Therefore, the objective of this study was to evaluate 25 succulent plant species for green roof applications in the midwestern United States by measuring the effect of substrate depth on initial growth rates, coverage, and survival.

\section{Materials and Methods}

An initial growth and coverage study was conducted on raised roof platforms at the Horticulture Teaching and Research Center at Michigan State University (MSU), East Lansing, Mich. The study was a split-plot completely random design with substrate depth as the main plot factor and species as the subplot factor. Each species was replicated eight times within each substrate depth for a total of 600 plants.

Platforms. Twenty-four $123 \mathrm{~cm} \times 123-\mathrm{cm}$ raised-roof platforms were constructed. Each pressure-treated wood platform was built per the same ASTM International standards that would be required for a commercial building and equipped with layers of insulation, waterproofing, a green roof drainage system, root barrier, substrate, and a $2 \%$ slope for drainage. In each plot, excess water drained through three drilled holes at the base of the slope $\approx 3 \mathrm{~cm}$ in diameter and covered by a mesh filter screen. The tops of each individual wood frame plot were bordered with flexible meter tape for rescaling and orientating the images.

Platforms included a green roof drainage layer (XF108) and vegetation carrier (XF301; Wolfgang Behrens Systementwicklung, $\mathrm{GmbH}$, Groß Ipener, Germany). The drainage layer consisted of a geotextile fabric with attached nylon coil. The nylon coils faced down when installed and the total thickness of this layer was $\approx 1.5 \mathrm{~cm}$. A water retention fabric layer, $\approx 0.75 \mathrm{~cm}$ thick, was added with the capacity to hold up to $800 \mathrm{~g} \cdot \mathrm{m}^{-2}$ of water. The water retention fabric layer was composed of a recycled synthetic fiber mixture of polyester, polyamide, polypropylene, and acrylic fibers. The vegetation carrier consisted of a geotextile fabric with nylon coils attached and filled with substrate.

Substrate. Substrate depths of $2.5 \mathrm{~cm}$, $5.0 \mathrm{~cm}$, and $7.5 \mathrm{~cm}$ were randomly assigned to the 24 platforms. Substrate consisted of $40 \%$ heat-expanded slate (gradation of 3 to $5 \mathrm{~mm}$ ) (PermaTill; Carolina Stalite Company, Salisbury, N.C.), 40\% U.S. Golf Association grade sand (Osburn Industries, Taylor, Mich.), 10\% Michigan Peat (Osburn Industries, Taylor, Mich.), 5\% Dolomite (Osburn Industries), 3.33\% composted yard waste (Renewed Earth, Kalamazoo, Mich.), and $1.67 \%$ composted turkey litter (Herbruck's, Saranac, Mich.). Substrate proportions are based on volume. At the time of planting, electrical conductivity and $\mathrm{pH}$ of the media were $3.29 \mathrm{mmho} \cdot \mathrm{cm}^{-1}$ and 7.9 , respectively. All treatments had $100 \mathrm{~g} \cdot \mathrm{m}^{-2}$ of Nutricote type $100,18 \mathrm{~N}-6 \mathrm{P}-9 \mathrm{~K}$ controlledrelease fertilizer (Agrivert, Webster, Texas) hand-applied $47 \mathrm{~d}$ after planting on 28 July 2003 and the following summer on 29 July 2004 at the same rate.

Plant species. Stem and leaf cuttings of 25 Crassulaceaen plant species were excised from stock plants growing in the MSU Plant Science Greenhouses on 11 June 2003. Length of the unrooted cuttings ranged from 2 to $4 \mathrm{~cm}$ but were uniform in size within species. Cuttings were stored overnight at $5{ }^{\circ} \mathrm{C}$ and propagated the next day on the outdoor platforms (day 1). Cuttings were placed on $20-\mathrm{cm}$ centers with 25 individual species per plot. The location of individual cuttings within each plot was randomly assigned. Species included Graptopetalum paraguayense subsp. Rose, Phedimus spurius Raf. 'Leningrad White', Rhodiola pachyclada L., $R$. trollii L., Sedum acre L., S. album L. 'Bella d'Inverno', S. clavatum C., S. confusum Hemsley, S. dasyphyllum L. 'Burnati', S. dasyphyllum L. 'Lilac Mound', S. diffusum W., S. hispanicum L., S. kamtschaticum Fisch., $S$. mexicanum Britt., S. middendorffianum L., S. moranense Kunth, S. pachyphyllum Clausen, S. reflexum L., S. sediforme J., S. 'Rockery Challenger' H., S. 'Spiral Staircase' H., $S$. spurium Bieb. 'Summer Glory', $S$. surculosum var. luteum Cos., $S . \times$ luteoviride $\mathrm{C}$., and S. $\times$ rubrontinctum $\mathrm{C}$.

During the first $22 \mathrm{~d}$ of the study, the platforms were covered with a shadecloth. To help acclimate the plants, the shadecloth was removed, except on bright sunny days, up until day 31 , at which time it was removed permanently.

Irrigation. During the establishment period, plots were overhead-irrigated with Rain Bird (Azusa, Calif.) Xerigation XS-180 spray heads fixed to $30.5-\mathrm{cm}$ Polyflex risers. The risers were placed at increments measuring $120 \mathrm{~cm}$. For the first $20 \mathrm{~d}$, the plots were irrigated for 5-min cycles at 0700, 1100, 1400, 1700 , and 2000 HR. Each 5-min cycle applied enough water to saturate each plot, misting $\approx 4.0 \mathrm{~mm}(30 \mathrm{ml})$ per plot. Irrigation duration was reduced to 2 -min cycles from days 21 to 41. After day 41, automated irrigation ended but occurred periodically to maintain plant health the first year. In the second growing season, supplemental irrigation was not used.

Weed species. During the establishment period, numerous weed seedlings emerged and included Cirsium arvense L. Eleusine indica L., Eragrostis cilianensis All., Mollugo verticillata L., Panicum capillare L., Populus deltoides Marshall, Salix nigra Marsh., and Senecio vulgaris L. Emerging weeds were hand pulled up to day 33. They were then allowed to grow until day 86 , at which time all weeds were removed. Thereafter, plots were managed to remain weedfree for ease of data collection to maintain the original goals of measuring growth rates for desired planted species.

Data collection. Measurements of twodimensional plant coverage were recorded by taking weekly digital images (32 MB, $1800 \times$ 1200 pixel, fine quality). A portable camera stand was constructed to raise a camera $\approx 163 \mathrm{~cm}$ above the platforms. A digital camera (FUJIFILM MX-2900 zoom, 2.3 mega pixels; Fuji Photo Film Co., Ltd., Tokyo, Japan) equipped with an F3.3/F7.6 wide conversion lens was suspended on the camera stand. The focal distance was set at 22 $\mathrm{mm}$ and the focal range set at $0.9 \mathrm{~m}$. Although planted on 12 June 2003, images were first taken on 8 July (day 27). Weekly analysis occurred during the initial growing season defined as the time up until the plants entered dormancy in late fall and a hard frost occurred on 28 Oct. 2003 (day 139). Data collection resumed the next spring on 24 Mar. 2004 (day 287). This method was used until 19 May 2004 (day 343) when it became too difficult to distinguish individual species because plant canopies began to overlap.

Survival rates were recorded during establishment, after the first growing season, the next spring, and at the end of the second growing season (Table 1). The establishment period was defined as the period up to $7 \mathrm{~d}$ after supplemented irrigation ended when $90 \%$ of the individuals had rooted. Persistence for the first year was scored on 28 Oct. 2003 (day 139) after a hard frost. To consider overwintering success, presence of individuals at day 139 were compared with their presence on 12 May 2004 (day 336). A final assessment of persistence during the second growing season was made on day 482 after a hard frost on 5 Oct. 2004.

Image analysis. Plant growth rates and horizontal vegetative coverage were determined in a nondestructive method by using SigmaScan Pro 5.0 image analysis software (SPSS Science, Chicago). Vertical height was not measured. Coverage (plant community development) in each plot was measured to compare growth relative to substrate depth (Fig. 1). Digital images were analyzed to determine the percentage of the total horizontal vegetative canopy attributed to each individual. Image area was delineated for the quadrat area using the two-point rescaling function, and then individual plants were analyzed using the manual trace mode (Olmstead et al., 2004). Manual trace mode was necessary because the software program could not automatically distinguish color, intensity, and hue differences between plant materials and substrate. A preliminary test established the accuracy of the method of taking weekly images, analyzing them in an image analysis program, and converting to actual centimeters squared. By measuring paper images of a known area $\left(10 \mathrm{~cm}^{2}\right)$, it was determined that the measurements were $94 \%$ accurate relative to actual size.

Vegetative growth was recorded by weekly image analysis beginning on day 27 (8 July 2003), after the $26 \mathrm{~d}$ establishment period when individual cuttings rooted. Because of snow cover, analysis of weekly images resumed the next spring on day 287 (24 Mar. 2004). Because it became too difficult to distinguish individual species boundaries, image analysis collection ended on day 342 (18 May 2004).

As a result of size variability among propagules after the $26 \mathrm{~d}$ establishment 


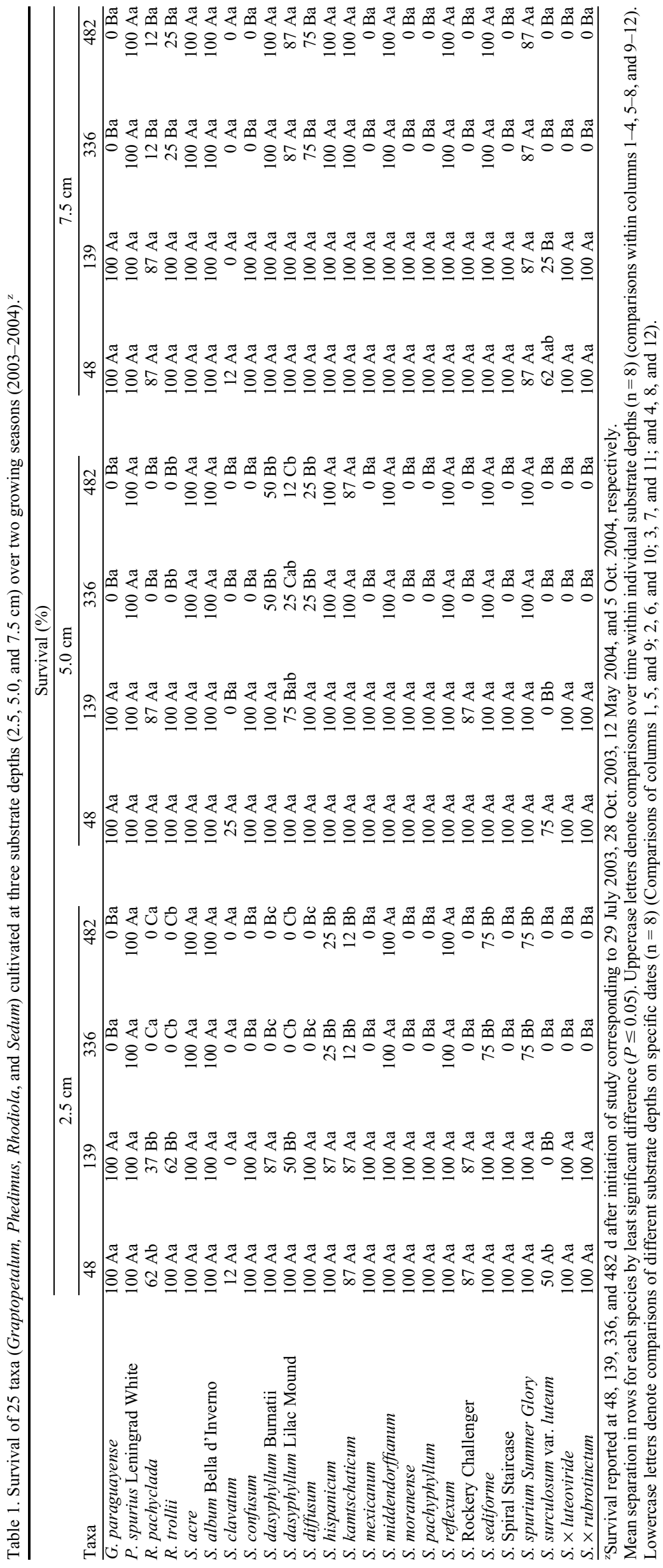

period and at the beginning of the second season, the increase in area was calculated to show vegetative groundcover relative to starting size. During 2003, this increase was defined as final area of coverage on day 139 (28 Oct.) minus the initial coverage when image analysis was first used on day 27 (8 July). Likewise, this value was calculated the second season (2004) as the final area on day 342 (18 May) minus the initial on day 287 (23 Mar.) that spring. Measurements for each species were averaged across the eight replications at each species depth. Growth rate was defined using the area of coverage graphs to measure the slope of area divided by time.

Statistical analysis. Data were analyzed separately for 2003 and 2004 years. Significant differences between species growth and depth on specific weeks were determined using multiple comparisons (least significant differences) with Tukey-Kramer adjustments (PROC MIXED, SAS version 8.02; SAS Institute, Cary, N.C.). Survival percentages were compared using a mixed model in which time and depth were factors and species was nested in depth. Survival data did not require a log transformation because it was observed to be normally distributed. Overall coverage of vegetation analyzed at the end of the study was tested using least significant differences (PROC GLM, SAS version 8.02; SAS Institute).

\section{Results and Discussion}

Survival. In general, plants grown in the deeper substrate depths of 5.0 and $7.5 \mathrm{~cm}$ exhibited higher survival rates than those grown at the $2.5-\mathrm{cm}$ depth (Table 1). All individual cuttings did not survive the propagation period; however, no single species experienced complete mortality for all eight replications at any depth. Rhodiola pachyclada, S. clavatum, S. kamtschaticum, $S$. 'Rockery Challenger', and S. surculosum var. luteum exhibited less than $100 \%$ propagation survival on some substrate depths after supplemental irrigation was ended. In addition, S. clavatum and $S$. surculosum var. luteum displayed less than $100 \%$ propagation survival at all three depths.

At the end of the first season (day 139), plant mortality was most prominent at the $2.5-\mathrm{cm}$ depth where survival percentage declined for $R$. pachyclada, $R$. trollii, S. dasyphyllum 'Lilac Mound', and S. surculosum var. luteum. Individuals grown in the $7.5-\mathrm{cm}$ depth were least affected by the end of the first season because only $S$. surculosum var. luteum experienced a significant decline in survival. Regardless of depth, $S$. clavatum did not survive the first growing season and $S$. surculosum var. luteum only survived at the 7.5-cm depth.

In addition to initial establishment and growth, plant hardiness of the shoots and root systems are critical for longevity, stability, and appearance of extensive green roofs (Boivin et al., 2001; Durhman et al., 2004; Getter and Rowe, 2006). Substrate depth appeared to influence plant cold hardiness 
with deeper substrate depths of 5.0 and 7.5 $\mathrm{cm}$ supporting greater overwintering survival than those grown at the $2.5-\mathrm{cm}$ depth. At the shallow substrate depth of $2.5 \mathrm{~cm}$, only nine of the 25 species overwintered compared with 12 and 14 species for the 5.0- and $7.5-\mathrm{cm}$ depths, respectively. Deeper substrates likely provided greater moisture retention and root protection from temperature fluctuations and allowed for more vertical space for plant roots to grow before reaching the root barrier. A more stable environment allows plants to grow stronger and healthier, which affects their ability to survive harsh climatic conditions of drought and temperatures. However, even with deeper substrates, mortality during winter could be the result of death of the root systems, which are generally not as cold-tolerant as the tops of plants (Wu and Cosgrove, 2000).

In this study, one must remember that the plants were growing on roof platforms so the ambient air temperature was the same above and below the green roof. This would make the root systems more susceptible to freezing. The winter of 2003-2004 was typical for East Lansing with a minimum temperature of $-24.3{ }^{\circ} \mathrm{C}$ recorded at the research site and $141 \mathrm{~d}$ with a minimum temperature below $0{ }^{\circ} \mathrm{C}$ (Fig. 2). On the roof of a heated building, the rooting substrate would be warmed somewhat from heat transfer from the building below. If freezing of root systems was the cause of death, then one would expect that if a particular species survived on a roof platform, then it would also survive on the roofs of unheated and heated buildings.

Rhodiola pachyclada, R. trollii, S. dasyphyllum 'Burnatii,' S. dasyphyllum 'Lilac Mound,' S. diffusum, S. hispanicum, S. kamtschaticum, $S$. sediforme, and $S$. spurium 'Summer Glory' all increased their survival rates when grown in deeper substrates. No plants of Sedum dasyphyllum 'Burnatii' survived at $2.5 \mathrm{~cm}$, but survival increased to $50 \%$ and $100 \%$ at 5.0 and $7.5 \mathrm{~cm}$, respectively. Similarly, S. hispanicum and S. kamtschaticum exhibited a dramatic increase in survival rates when the depth was increased from 2.5 to $5.0 \mathrm{~cm}$. At the end of the second season, all plants of five species were still alive regardless of substrate depth. Knowledge of how a species will perform at various substrate depths is important when choosing plant species for a green roof where substrate depth must be kept to a minimum because of building weight restrictions.

Results for $S$. acre, S. album, S. kamtschaticum, S. middendorffianum, S. reflexum, and $S$. spurium support previous research that these species can survive on extensive green roofs in the midwestern United States (Monterusso et al., 2005; Rowe et al., 2006a, 2006b). In addition, all P. spurius 'Leningrad White' and S. sediforme survived regardless of substrate depth. Species such as $S$. mexicanum, which exhibited high coverage values and a fast rate of establishment during the first growing season but no winter survival, may be more suited for green roofs in warmer climates.
Growth rate. Substrate depth affected growth rate, although not immediately (Fig. 1 ). This is probably because the developing root systems were not yet large enough to exploit the entire depth of the substrate. Growth after establishment varied across species. Depending on substrate depth, several species established and grew quickly early in the season. Differences in initial growth rates could be attributed to individuals' propagation potential, aggressiveness to establish in an open area, and resource allocation.

When image analysis first began on day 27 (8 July 2003) until day 55 (5 Aug. 2003), S. album 'Bella d'Inverno' $\left(1.6 \mathrm{~cm}^{2} \cdot \mathrm{d}^{-1}\right)$ was
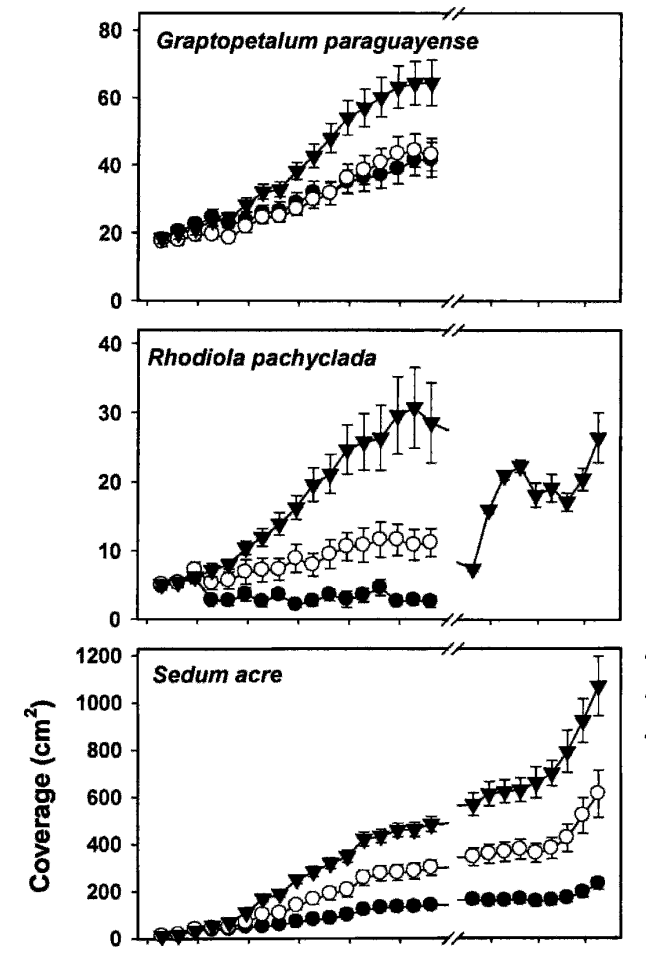
than $1.5 \mathrm{~cm}^{2}$ in coverage per day at a
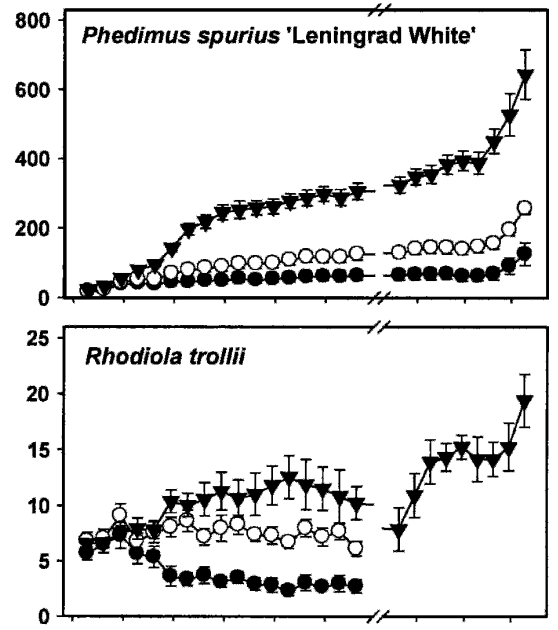

$P$. spurius 'Leningrad White' (2.5), S. acre (2.0), S. album 'Bella d'Inverno' (3.5), $S$. diffusum (1.7), S. hispanicum (1.5), S. mexicanum (3.2), S. middendorffianum (1.6), and S. spurium 'Summer Glory' (2.2).

Between days 55 and 125 (14 Oct. 2003), three, eight, and 14 species exhibited a growth rate greater than $1.5 \mathrm{~cm}^{2} \cdot \mathrm{d}^{-1}$ at the

the only species that exhibited a growth rate species at a $5.0 \mathrm{~cm}$ with $S$. album 'Bella d'Inverno' (1.9), S. mexicanum (1.7), and S. spurium 'Summer Glory' (1.8) all exhibiting growth greater than $1.5 \mathrm{~cm}^{2} \cdot$ day $^{-1}$. At $7.5 \mathrm{~cm}$, eight species were above this value:

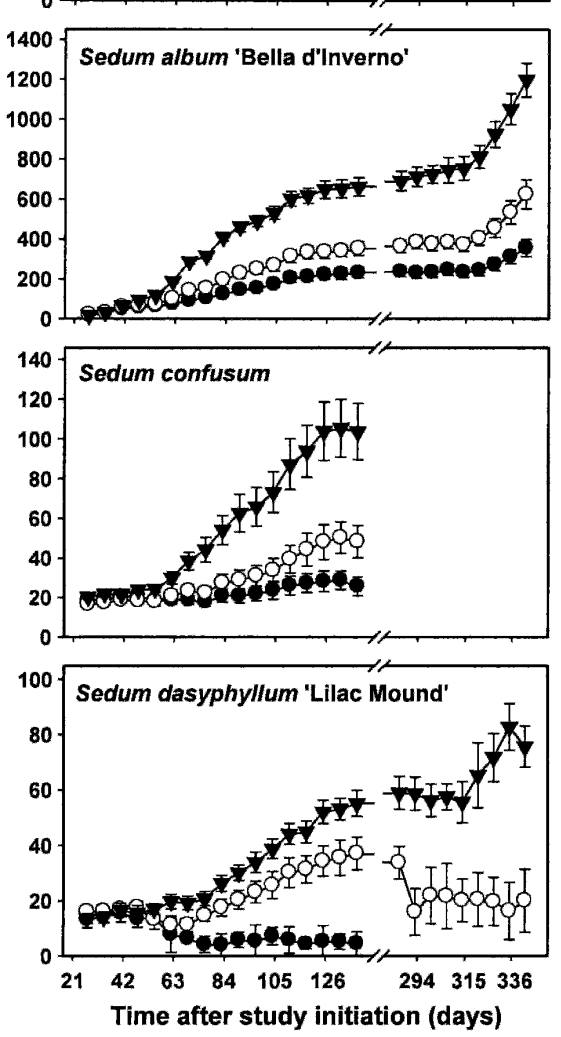

Fig. 1. Growth of 25 taxa (Graptopetalum, Phedimus, Rhodiola, and Sedum) cultivated on green roof platforms at three depths $(2.5,5.0$, and $7.5 \mathrm{~cm})$. Growth was calculated from digital image analysis. Data collected once a week for 20 weeks, resumed the next spring on week 41, and ended on week 49 when plants were too dense to discriminate. Error bars represent standard error. Break in x-axis denotes winter. 


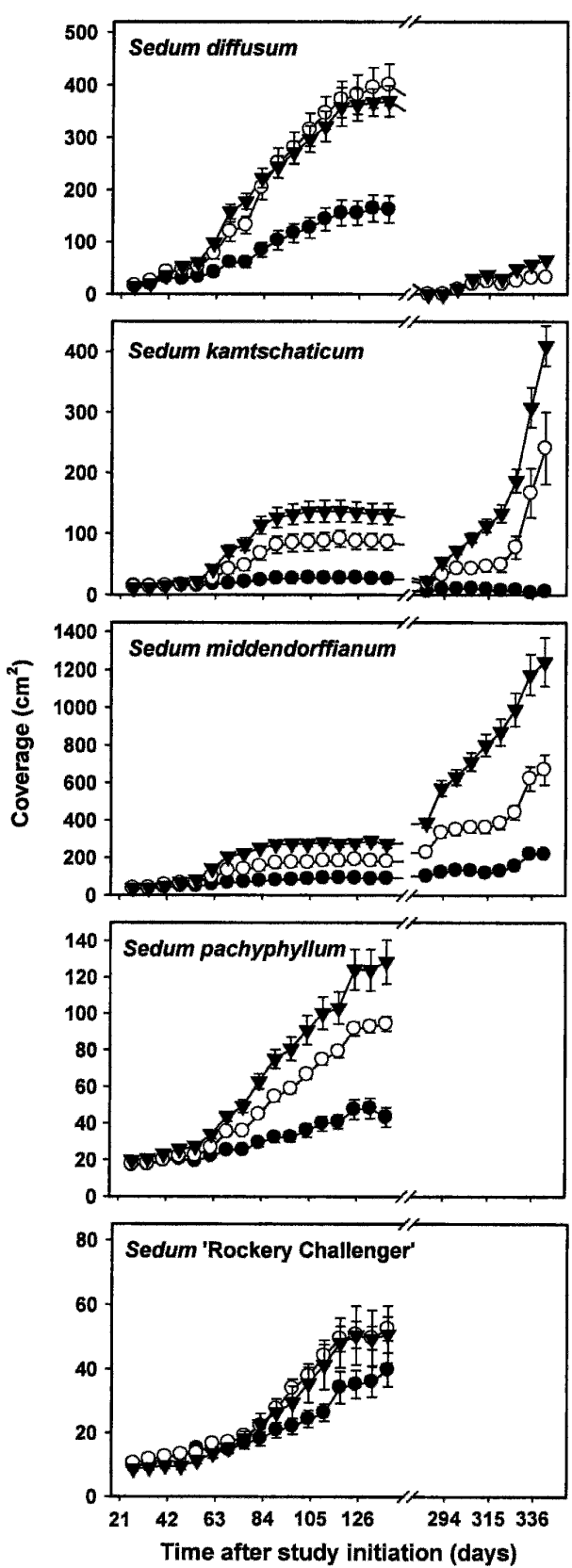

Fig. 1. Continued

2.5-, 5.0-, and 7.5-cm depths, respectively. At $2.5 \mathrm{~cm}$, species included S. album 'Bella d'Inverno' (2.2), $S$. diffusum (1.7), and $S$. mexicanum (1.7). At $5.0 \mathrm{~cm}, S$. acre (3.3), S. album 'Bella d'Inverno' (3.7), S. diffusum (4.7), S. hispanicum (2.8), S. mexicanum (4.0), $S$. middendorffianum (1.7), S. reflexum (1.5), and $S$. sediforme (1.9) fit into this category. At $7.5 \mathrm{~cm}$, the list included $P$. spurius 'Leningrad White' (2.9), S. acre (5.6), S. album 'Bella d'Inverno' (7.5), $S$. dasyphyllum 'Burnati' (2.7), S. diffusum (4.3), S. hispanicum (4.0), S. kamtschaticum (1.6), S. mexicanum (7.2), $S$. middendorffianum (2.8), $S$. moranense (1.6), S. reflexum (2.7), S. sediforme (2.9), $S$. spurium 'Summer Glory' (2.1), and $S . \times$ rubronticum (1.6). From day 125 to the first hard frost on day 139 (28 Oct. 2003), S. acre (1.8) was the only species at any depth that
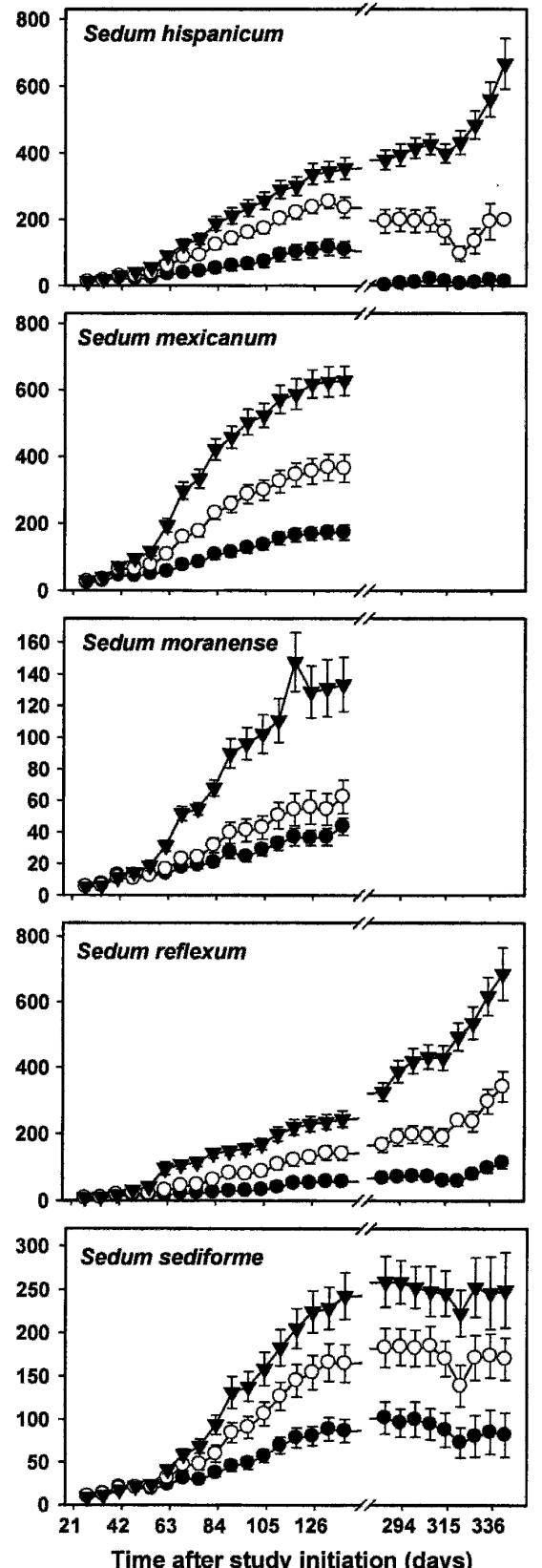

Time after study initiation (days)

had a growth rate greater than $1.5 \mathrm{~cm}^{2} \cdot \mathrm{d}^{-1}$. This occurred at a depth of $7.5 \mathrm{~cm}$.

After winter, growth resumed for most species the second season. There was little or no observable vegetation present on day 287 for deciduous species such as $S$. kamtschaticum and R. pachyclada. However, because regeneration occurred later in spring, growth rates improved. Some species had vegetative dieback in the plant's center (semideciduous), although surrounding tissues were actively recovering from winter injury or growing. For this observation, plant material that looked healthy (turgid or leaf color similar to the previous year's growth) was recorded. Species that exhibited dieback included S. dasyphyllum 'Burnatii', S. dasyphyllum 'Lilac Mound', S. hispanicum, and $S$. album 'Bella d'Inverno'. However, by May, winter injury was no longer observed. One interesting observation was $S$. middendorffianum, S. spurium 'Summer Glory', and S. kamtschaticum had much faster growth rates in the second year compared with their performance the prior year. Sedum acre and S. album 'Bella d'Inverno' had consistently increasing growth rates.

During this second season, there was zero to minimal growth at $2.5 \mathrm{~cm}$ between days 286 (23 Mar. 2004) and 314 (20 Apr. 2004) with $S$. middendorffianum displaying the highest growth rate of $0.6 \mathrm{~cm}^{2} \cdot \mathrm{d}^{-1}$. At $5.0 \mathrm{~cm}, S$. middendorffianum (4.7) was still the only species with a growth rate above $1.5 \mathrm{~cm}^{2} \cdot \mathrm{d}^{-1}$. At a depth of $7.5 \mathrm{~cm}, P$. spurius 'Leningrad White' (2.5), S. acre (3.3), S. album 'Bella d'Inverno' (2.3), S. kamtschaticum (3.3), S. middendorffianum (14.7), $S$. reflexum (3.7), and $S$. spurium 'Summer Glory' (2.2) all exhibited rapid early growth. Other species such as $S$. mexicanum, $S$. moranense, and $S . \times$ rubronticum that displayed rapid growth the previous year were absent at this stage because they did not survive the winter.

During the next $28 \mathrm{~d}$ up until day 342 (18 May 2004), rapid growth occurred for $P$. spurius 'Leningrad White' (2.2), S. acre (2.6), S. album 'Bella d'Inverno' (4.3), $S$. middendorffianum (3.6), $S$. reflexum (1.9), and $S$. spurium 'Summer Glory' (2.5) at $2.5 \mathrm{~cm}$ and $P$. spurius 'Leningrad White' (4.2), S. acre (8.9), S. album 'Bella d'Inverno' (9.0), S. kamtschaticum (6.9), S. middendorffianum (11.0), S. reflexum (5.4), and S. spurium 'Summer Glory' (7.8) at $5.0 \mathrm{~cm}$. At 7.5 $\mathrm{cm}$, these values were even higher: $P$. spurius 'Leningrad White' (8.9), S. acre (14.6), S. album 'Bella d'Inverno' (15.8), S. hispanicum (9.6), S. kamtschaticum (10.6), S. middendorffianum (15.8), S. reflexum (9.1), and S. spurium 'Summer Glory' (6.6). After day 342 , it became too difficult to distinguish species by image analysis from digital photographs because some species were beginning to grow over the top of others to form multiple canopy layers. However, visual observations confirmed that plants continued to spread throughout the second growing season (Durhman, 2005). Sedum acre, S. album 'Bella d'Inverno', and $S$. middendorffianum displayed the most growth and exhibited the highest percentage of cover by day 482 ( 5 Oct. 2004).

Across all species, plant vigor (i.e., the fastest growth rates) was greatest at the deepest substrate depth of $7.5 \mathrm{~cm}$. Although the $2.5-\mathrm{cm}$ depth did not promote growth to the same extent as the deeper substrates, plants remained alive. This agrees with the work of VanWoert et al. (2005b) who reported that watering was necessary every $14 \mathrm{~d}$ to support growth of a mixture of sedum in a green roof substrate with a $2-\mathrm{cm}$ media depth but only once every $28 \mathrm{~d}$ when the substrate depth was increased to $6 \mathrm{~cm}$. Although growth was diminished, these plants survived $88 \mathrm{~d}$ without water (VanWoert et al., 2005b). Over time, growth rates within depths varied across plant species, 

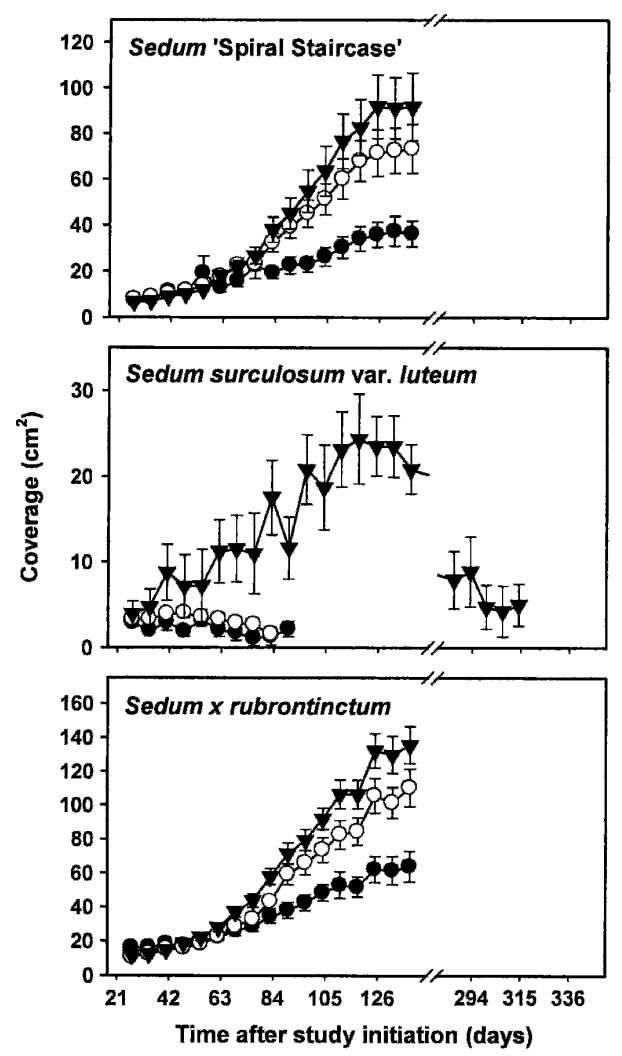

Fig. 1. Continued

especially for some species including S. acre, $S$. album 'Bella d'Inverno', S. diffusum, S. hispanicum, $S$. mexicanum, and $S$. middendorffianum (Fig. 1). This is attributable in part to favorable growing conditions such as amount and duration of rainfall and temperatures (Fig. 2).

Coverage. As expected, those species that exhibited the fastest growth rate covered the greatest area when image analysis ended on day 343 (Fig. 1). Species with the greatest amount of coverage included $P$. spurius 'Leningrad White', S. acre, S. album 'Bella d'Inverno', S. hispanicum, S. middendorffianum, and $S$. reflexum. An exception was $S$. mexicanum, which exhibited high coverage values and a fast rate of establishment across all depths during the first growing season. However, it was not able to survive winter and completely disappeared by the second season. In fact, at the end of the first season, $S$. mexicanum covered a greater area than all other species except for $S$. album 'Bella d'Inverno'.

For most species, coverage was significantly different at each depth with the greatest area of coverage occurring for plants growing in $7.5 \mathrm{~cm}$ of substrate (Fig. 1). By day 343 , plants growing in $2.5,5.0$, and 7.5 $\mathrm{cm}$ of substrate had reached $47 \%, 74 \%$, and $96 \%$ coverage, respectively $(P \leq 0.05)$. The $47 \%$ coverage on the $2.5-\mathrm{cm}$ depth had still not reached the minimum $60 \%$ coverage to be approved as a green roof according to German FLL standards (FLL, 1995). The most vigorous spreader, $S$. middendorffianum, covered $1242 \mathrm{~cm}^{2}$ at a depth of $7.5 \mathrm{~cm}$ but only
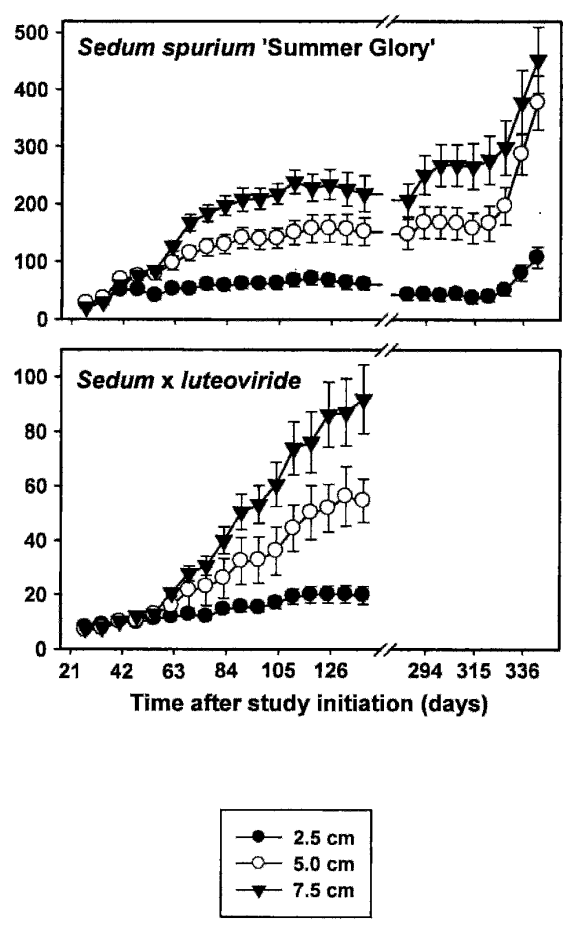

$670 \mathrm{~cm}^{2}$ and $220 \mathrm{~cm}^{2}$ at 5.0 and $2.5 \mathrm{~cm}$, respectively (Fig. 1). However, not all species exhibited a significant difference in coverage between depths of 5.0 and $7.5 \mathrm{~cm}$. Sedum spurium 'Summer Glory' covered 377 and $452 \mathrm{~cm}^{2}$ at 5.0 and $7.5 \mathrm{~cm}$, respectively, but only $108 \mathrm{~cm}^{2}$ at a depth of $2.5 \mathrm{~cm}$.

Increases in coverage within each season also mirrored overall coverage and was dependent on substrate depth (Table 2). Similar to total coverage, during the image analysis phase of the second season, the increase in horizontal growth for Sedum spurium 'Summer Glory' at depths of 5.0 $\left(229 \mathrm{~cm}^{2}\right)$ and $7.5 \mathrm{~cm}\left(245 \mathrm{~cm}^{2}\right)$ was not different but was much greater than horizontal growth at $2.5 \mathrm{~cm}\left(65 \mathrm{~cm}^{2}\right)$. There were also differences among seasons. Some species such as $S$. dasyphyllum 'Burnatii', $S$. dasyphyllum 'Lilac Mound', and S. sediforme did not expand further or decreased in coverage regardless of substrate depth (Table 2 ) during the second growing season. This may be the result of increased competition during the second season from plants that were more vigorous. Fast establishment and substrate coverage are desirable characteristics for green roof plant taxa. Fast initial growth is important because the faster the plants cover the substrate surface, the fewer the number of plants required and the less expensive they will be to purchase and install.

Life form characteristics influenced species survival, growth, and coverage. Raunkiaer (1934) classified the genus Sedum as passive chamaephytes, meaning evergreen or deciduous vegetative shoots lay along the ground and remain intact at the beginning of the unfavorable season. Evergreen species such as $S$. acre and $S$. album retain their vegetation over the Michigan winter. Additionally, their vegetative shoots quickly root and grow in different areas of the plots early in the growing season. In the spring, they have an obvious spatial advantage by predominating a particular area within the plot. In contrast, deciduous plants like S. kamtschaticum are not frost-tolerant and aboveground shoot tissues die in late fall with adverse weather conditions, although new vegetative growth occurs from regenerative buds in the spring. However, this influences the coverage present early in the season. They are at a disadvantage because they must compete spatially against evergreen species; however, their growth rates are comparable later in the growing season (Fig. 1).

Although not apparent in this study, improved coverage and presence at the end of the second growing season by S. hispanicum was attributable mainly to its prolific reseeding ability in late summer, especially compared with other species tested. In the second year, S. hispanicum flowered throughout June and July with seedlings emerging by the beginning of August. Other species that reseeded in the second season include $S$. acre and S. album 'Bella d'Inverno'. Overall, plants selected for this trial generally reproduce easily by asexual means of stem or leaf cuttings without the use of commercial rooting compounds (Stephenson, 2002). Over time, original plants could have easily reestablished themselves in the plots by vegetative means, thereby increasing their coverage and presence at the end of the study.

\section{Conclusion}

Most of the species examined within this study have not been previously reported for use on green roofs in the Michigan climate. Furthermore, some of these species and cultivars do not have published USDA hardiness zones. Therefore, this study offers new plant recommendations for use on green roofs. Of the 25 species initially planted, only $47 \%$ survived in the deepest substrate of 7.5 $\mathrm{cm}$. Recommended species at the depths tested for climates similar to southern Michigan include $P$. spurius 'Leningrad White', $S$. acre, $S$. album 'Bella d'Inverno', $S$. middendorffianum, $S$. reflexum, $S$. sediforme, and $S$. spurium 'Summer Glory'. Subsidiary species that are present at specific substrate depths but may not exhibit an ability to initially cover large areas include $S$. dasyphyllum 'Burnatii', S. dasyphyllum 'Lilac Mound', S. diffusum, S. hispanicum, and S. kamtschaticum. The primary deterrent for these subsidiary species was little to no survival at 2.5 $\mathrm{cm}$. Deeper substrates promoted greater survival and growth for nearly all species tested; however, in the shallowest depth of $2.5 \mathrm{~cm}$, several species were observed to form stable 

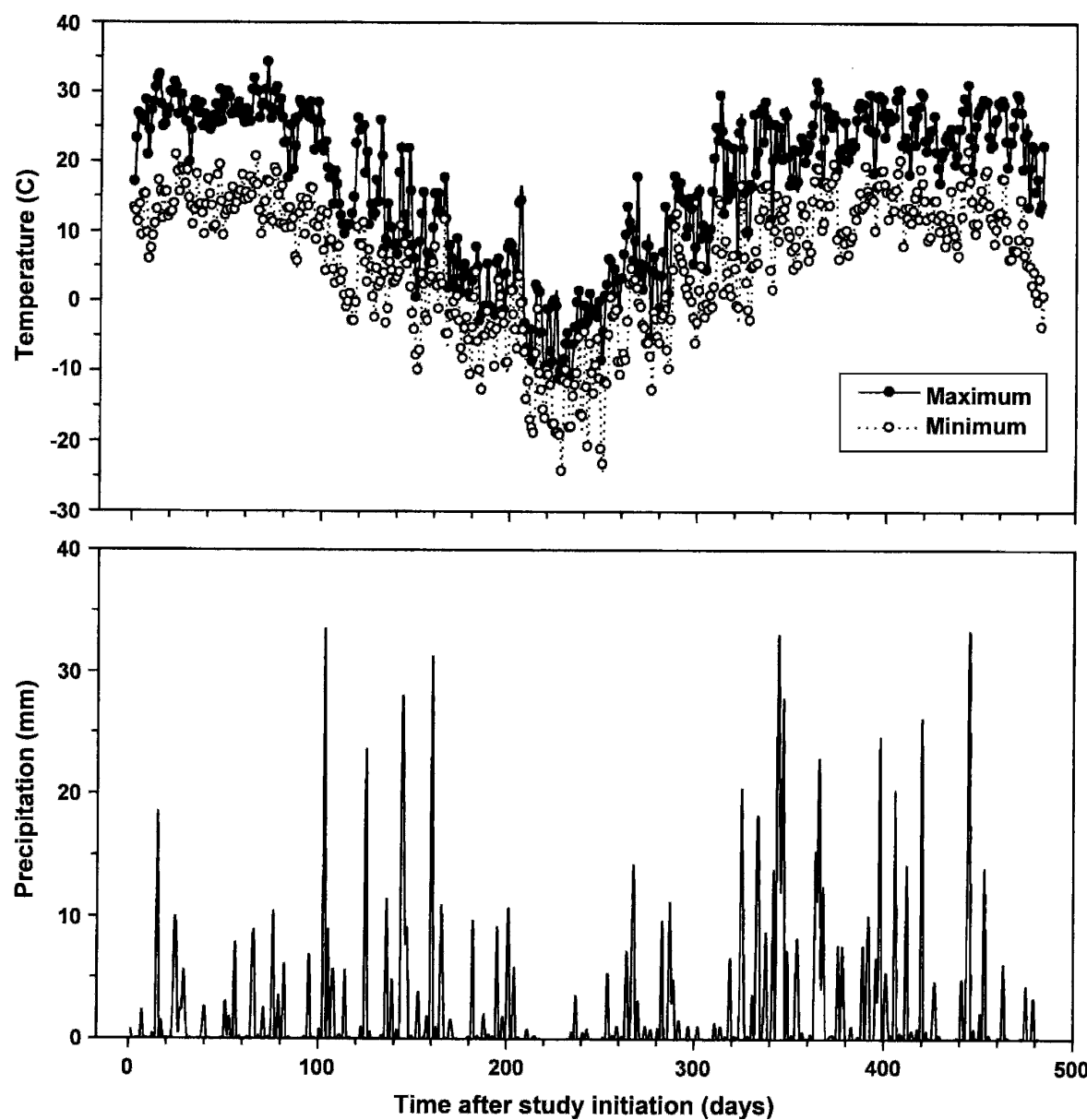

Fig. 2. Daily maximum and minimum temperatures $\left({ }^{\circ} \mathrm{C}\right)$ and precipitation (millimeters) during the experimental study (12 June 2003 through 06 Oct. 2004). Weather data were taken using the Michigan Automated Weather Network's East Lansing weather station (located adjacent to the research site).

Table 2. Increase in coverage $\left(\mathrm{cm}^{2}\right)$ as calculated from image analysis from days 27 to 139 (8 July 2003 to 28 Oct. 2003) and 287 to 343 (24 Mar. 2004 to 19 May 2004).

\begin{tabular}{|c|c|c|c|c|c|c|}
\hline \multirow[b]{3}{*}{ Taxa } & \multicolumn{6}{|c|}{ Increase in area of coverage $\left(\mathrm{cm}^{2}\right)$ within each season } \\
\hline & \multicolumn{3}{|c|}{2003 Depth $(\mathrm{cm})$} & \multicolumn{3}{|c|}{2004 Depth $(\mathrm{cm})$} \\
\hline & 2.5 & 5 & 7.5 & 2.5 & 5 & 7.5 \\
\hline G. paraguayense & & $26 \mathrm{a}$ & $46 \mathrm{a}$ & & & \\
\hline P. spurius Leningrad White & $47 \mathrm{~b}$ & $106 \mathrm{~b}$ & $281 \mathrm{a}$ & $61 \mathrm{~b}$ & $127 \mathrm{ab}$ & $320 \mathrm{a}$ \\
\hline R. pachyclada & $-2 \mathrm{a}$ & $6 a$ & $23 \mathrm{a}$ & & & 19 \\
\hline R. trollii & $-3 \mathrm{a}$ & $-1 \mathrm{a}$ & $3.6 \mathrm{a}$ & & & 12 \\
\hline S. acre & $128 \mathrm{c}$ & $288 \mathrm{~b}$ & $472 \mathrm{a}$ & $67 \mathrm{c}$ & $265 \mathrm{~b}$ & 501 \\
\hline S. album Bella d'Inverno & $210 \mathrm{c}$ & $330 \mathrm{~b}$ & $641 \mathrm{a}$ & $118 \mathrm{c}$ & $260 \mathrm{~b}$ & $507 \mathrm{a}$ \\
\hline S. clavatum & & & & & & \\
\hline S. confusum & $7 \mathrm{a}$ & $31 \mathrm{a}$ & $83 \mathrm{a}$ & & & \\
\hline S. dasyphyllum Burnatii & $9 \mathrm{c}$ & $106 \mathrm{~b}$ & $205 \mathrm{a}$ & & $7 \mathrm{a}$ & \\
\hline S. dasyphyllum Lilac Mound & $-9 \mathrm{a}$ & $21 \mathrm{a}$ & $42 \mathrm{a}$ & & $-14 \mathrm{a}$ & $17 \mathrm{a}$ \\
\hline S. diffusum & $149 \mathrm{~b}$ & $384 \mathrm{a}$ & $355 \mathrm{a}$ & & $32 \mathrm{a}$ & 66 a \\
\hline S. hispanicum & $98 \mathrm{c}$ & $224 \mathrm{~b}$ & $342 \mathrm{a}$ & $6 \mathrm{~b}$ & $3 \mathrm{~b}$ & $289 \mathrm{a}$ \\
\hline S. kamtschaticum & $12 \mathrm{~b}$ & $73 \mathrm{ab}$ & $121 \mathrm{a}$ & $-1 \mathrm{c}$ & $222 \mathrm{~b}$ & $387 \mathrm{a}$ \\
\hline S. mexicanum & $150 \mathrm{c}$ & $338 \mathrm{~b}$ & 599 a & & & \\
\hline S. middendorffianum & $58 \mathrm{c}$ & $144 \mathrm{~b}$ & $237 \mathrm{a}$ & $118 \mathrm{c}$ & $441 \mathrm{~b}$ & 855 \\
\hline S. moranense & $38 \mathrm{~b}$ & $57 \mathrm{~b}$ & $128 \mathrm{a}$ & & & \\
\hline S. pachyphyllum & $26 \mathrm{~b}$ & $77 \mathrm{ab}$ & $109 \mathrm{a}$ & & & \\
\hline S. reflexum & $50 \mathrm{~b}$ & $133 \mathrm{ab}$ & $235 \mathrm{a}$ & $46 \mathrm{c}$ & $175 \mathrm{~b}$ & $359 a$ \\
\hline S. Rockery Challenger & $30 \mathrm{a}$ & $42 \mathrm{a}$ & $42 \mathrm{a}$ & & & \\
\hline S. sediforme & $76 \mathrm{~b}$ & $155 \mathrm{ab}$ & $234 \mathrm{a}$ & $-20 \mathrm{a}$ & $-13 \mathrm{a}$ & $-10 \mathrm{a}$ \\
\hline S. Spiral Staircase & $29 \mathrm{a}$ & $66 \mathrm{a}$ & $85 \mathrm{a}$ & & & \\
\hline S. spurium Summer Glory & $35 \mathrm{~b}$ & $124 \mathrm{ab}$ & $197 \mathrm{a}$ & $65 \mathrm{~b}$ & $229 \mathrm{a}$ & 2.70 \\
\hline S. surculosum var. luteum & & & 17 & & & \\
\hline S. $\times$ luteoviride & $12 \mathrm{a}$ & $48 \mathrm{a}$ & $84 \mathrm{a}$ & & & \\
\hline S. $\times$ rubrotinctum & $48 \mathrm{~b}$ & $100 \mathrm{ab}$ & $124 \mathrm{a}$ & & & \\
\hline
\end{tabular}

Mean separation in rows among depths within each growing season for each taxa were tested using least significant difference with Tukey-Kramer adjustments $(P \leq 0.05)(\mathrm{n}=8)$. Tests were separated by year before analysis. Blanks denote no surviving plants for specific species. communities. In choosing a green roof system, it is important to consider both substrate depth and plant species growth factors for sustained growth.

\section{Literature Cited}

ASTM E 2400. 2006. Standard guide for selection, installation, and maintenance of plants for green roof systems. ASTM International, West Conshohocken, $\mathrm{Pa}$.

Boivin, M., M. Lamy, A. Gosselin, and B. Dansereau. 2001. Effect of artificial substrate depth on freezing injury of six herbaceous perennials grown in a green roof system. HortTechnology 11:409-412.

DeNardo, J.C., A.R. Jarrett, H.B. Manbeck, D.J. Beattie, and R.D. Berghage. 2005. Stormwater mitigation and surface temperature reduction by green roofs. Trans. ASAE 48:1491-1496.

Dunnett, N. and N. Kingsbury. 2004. Planting green roofs and living walls. Timber Press, Inc., Portland, Ore.

Dunnett, N. and A. Nolan. 2004. The effect of substrate depth and supplementary watering on the growth of nine herbaceous perennials in a semi-extensive green roof. Acta Hort. 643:305-309.

Durhman, A.K. 2005. Evaluation of Crassulacean species for extensive green roof applications. Michigan State University, East Lansing, MS thesis.

Durhman, A.K., D.B. Rowe, and C.L. Rugh. 2006 Effect of watering regimen on chlorophyll fluorescence and growth of selected green roof plant taxa. HortScience 41:1623-1628.

Durhman, A., N.D. VanWoert, D.B. Rowe, C.L. Rugh, and D. Ebert-May. 2004. Evaluation of Crassulacean species on extensive green roofs, p. 504-517. Proc. of 2nd North American Green Roof Conference: Greening Rooftops for Sustainable Communities, Portland, Ore., 2-4 June 2004. The Cardinal Group, Toronto.

FLL (Forschungsgesellschaft Landschaftsentwicklung Landschaftsbau). 1995. Guidelines for the planning, execution and upkeep of green-roof sites. Forschungsgesellschaft Landschaftsentwicklung Landschaftsbau. Bonn, Germany.

Gebauer, G. 1988. Carbon, nitrogen and water-use of $\mathrm{C} 3, \mathrm{C} 4$, and CAM plants: Comparative aspects. Acta Hort. 229:73-84.

Getter, K.L. and D.B. Rowe. 2006. The role of green roofs in sustainable development. HortScience 41:1276-1285.

Gómez-Campo, C. 1996. Plantas para la naturacion de azoteas: El genero Sedum L. Agricultura (Espana) 773:1029-1031.

Köehler, M. 2003. Plant survival research and biodiversity: Lessons from Europe, p. 313322. Proc. of 1st North American Green Roof Conference: Greening Rooftops for Sustainable Communities, Chicago, 29-30 May 2003. The Cardinal Group, Toronto.

Liu, K. 2004. Engineering performance on rooftop gardens through field evaluation. Journal of Roof Consultants Institute. 22:4-12.

Monterusso, M.A., D.B. Rowe, and C.L. Rugh. 2005. Establishment and persistence of Sedum spp. and native taxa for green roof applications. HortScience 40:391-396.

Olmstead, M.A., R. Wample, S. Greene, and J. Tarara. 2004. Nondestructive measurements of vegetative cover using digital image analysis. HortScience 39:55-59.

Raunkiaer, C. 1934. The life-forms of plants and statistical plant geography. Clarendon Press, Oxford, U.K. 
Rowe, D.B., M.A. Monterusso, and C.L. Rugh. 2006a. Assessment of heat-expanded slate and fertility requirements in green roof substrates. HortTechnology 16:471-477.

Rowe, D.B., C.L. Rugh, and A.K. Durhman. 2006b. Assessment of substrate depth and composition on green roof plant performance. Proc. of 4th North American Green Roof Conference: Greening Rooftops for Sustainable Communities, Boston, Mass., 10-12 May 2006. The Cardinal Group, Toronto.
Sayed, O.H. 2001. Crassulacean acid metabolism 1975-2000, a checklist. Photosynthetica 39:339-359.

Snodgrass, E.C. and L.L. Snodgrass. 2006. Green roof plants. Timber Press, Inc., Portland, Ore.

Stephenson, R. 2002. Sedum: Cultivated stonecrop. Timber Press, Inc., Portland, Ore.

Ting, I. 1985. Crassulacean acid metabolism. Ann. Rev. Plant Physiol. 36:595-622.

VanWoert, N.D., D.B. Rowe, J.A. Andresen, C.L. Rugh, R.T. Fernandez, and L. Xiao. 2005a.
Green roof stormwater retention: Effects of roof surface, slope, and media depth. J. Environ. Qual. 34:1036-1044.

VanWoert, N.D., D.B. Rowe, J.A. Andresen, C.L. Rugh, and L. Xiao. 2005b. Watering regime and green roof substrate design affect Sedum plant growth. HortScience 40:659-664.

$\mathrm{Wu}, \mathrm{Y}$. and D.J. Cosgrove. 2000. Adaptation of roots to low water potentials by changes in cell wall extensibility and cell wall proteins. J. Expt. Bot. 51:1543-1553. 